\title{
Towards a Carbon Neutral and Sustainable Campus: Case Study of NED University of Engineering and Technology
}

\author{
Atif Mustafa ${ }^{1, *(1)}$, Majida Kazmi ${ }^{2}$, Hashim Raza Khan ${ }^{2,3}$, Saad Ahmed Qazi ${ }^{2,3}$ and Sarosh Hashmat Lodi ${ }^{4}$ \\ 1 Faculty of Chemical and Process Engineering, NED University of Engineering and Technology, \\ Karachi 75270, Pakistan \\ 2 Faculty of Electrical and Computer Engineering, NED University of Engineering and Technology, \\ Karachi 75270, Pakistan; majidakazmi@neduet.edu.pk (M.K.); hashim@neduet.edu.pk (H.R.K.); \\ saadqazi@neduet.edu.pk (S.A.Q.) \\ 3 Neurocomputation Lab, National Centre of Artificial Intelligence, Karachi 75270, Pakistan \\ 4 Faculty of Civil and Petroleum Engineering, NED University of Engineering and Technology, \\ Karachi 75270, Pakistan; sarosh.lodi@neduet.edu.pk \\ * Correspondence: atifm@neduet.edu.pk; Tel.: +92-21-99052346
}

Citation: Mustafa, A.; Kazmi, M.; Khan, H.R.; Qazi, S.A.; Lodi, S.H. Towards a Carbon Neutral and Sustainable Campus: Case Study of NED University of Engineering and Technology. Sustainability 2022, 14, 794. https://doi.org/10.3390/ su14020794

Academic Editor: Jan K. Kazak

Received: 3 November 2021 Accepted: 27 December 2021 Published: 11 January 2022

Publisher's Note: MDPI stays neutral with regard to jurisdictional claims in published maps and institutional affiliations.

Copyright: (C) 2022 by the authors. Licensee MDPI, Basel, Switzerland. This article is an open access article distributed under the terms and conditions of the Creative Commons Attribution (CC BY) license (https:// creativecommons.org/licenses/by/ $4.0 /)$.

\begin{abstract}
Globally, universities are evaluating and targeting to reduce their carbon emissions and operate on a sustainable basis. The overall aim of this study revolves in addressing the following three questions: (1) How to calculate carbon footprint, including indicators selection, criteria, and measurement, for higher education institutions? (2) How to evaluate impact and effectiveness of various mitigation strategies in context of a higher education institution? (3) What are the possible limitations of approach selected for carbon footprint calculation. This paper presents estimation of the carbon footprint of NED University using a carbon calculator along with the identification of sources with maximum contribution to its carbon footprint. The carbon footprint of the NED University main campus for 2017 was calculated to be approximately 21,500 metric tons of equivalent $\mathrm{CO}_{2}$ and carbon footprint per student was 1.79 metric tons of equivalent $\mathrm{CO}_{2}$. Scope 1 and Scope 2 emissions each contributed nearly $7 \%$ of the carbon footprint, while Scope 3 emissions accounted for $85.6 \%$ of the carbon footprint. Major interventions such as switching to renewables, usage of energy efficient appliances, electric vehicles, and massive tree plantation inside and outside the campus were identified as the most effective mitigation strategies.
\end{abstract}

Keywords: carbon neutrality; green campus; carbon footprint; urban forests; Pakistan; sustainability

\section{Introduction}

In 2018, the Inter-governmental Panel on Climate Change (IPCC) special report delineated the status of limiting global temperatures to $1.5^{\circ} \mathrm{C}$ by outlining the economic, environmental, and social impacts of increasing temperature scenario. To limit warming, urgent action is compulsory to decrease global greenhouse gas (GHG) emissions $45 \%$ below 2010 levels by 2030, and ultimately accomplishing zero net emissions by 2050. Like other countries, Pakistan potentially faces a key climate change challenge and is among the top ten countries affected by Climate Change. A concerted effort by the government and public is required to bring unprecedented shifts in all aspects of the society. Educational institutions are fit to play key roles in promoting modernization and determining the scientific and societal standards [1]. They play an essential role in changing societies [2] and support major social changes that can significantly change behavioral patterns and cultural norms. For example, during the 1990s, higher education institutions (HEIs) in the US organized anti-tobacco campaigns alongside with drives for them to deprive the tobacco industry and to prohibit smoking on campuses nationwide [3]. Moreover, in the 1980s, HEIs used divestment from South African companies as a weapon to contest Apartheid. Hence, educational institutions not only educate students but also produce knowledge that 
nurtures a prosperous civil society. Globally, it has been proven that education plays an important part in indoctrinating sustainability principles in young minds, and concurrently makes the public cognizant about the principles of sustainability, subsequently enabling its incorporation into daily life activities $[4,5]$.

Moreover, large educational institutions including universities can be considered as small cities due to their big size, assorted populace, and the frequent multifaceted activities and operations happening in their campuses. Globally, many universities have adopted measures to limit the effects of their actions on the environment and to become more sustainable in their operations, and some have willingly dedicated their obligation towards sustainability by becoming signatories to international, national, or regional declarations and agreements like the Halifax and Talloires Declarations. The subjects of carbon neutrality and sustainability in educational campuses have become a universal consideration for university management authorities as the actions and procedures of universities have impacts on the environment [6-8]. Sustainable university can be defined as a higher educational institution that comprises and encourages the minimization of hostile environmental, economic, and societal impacts generated by use of their resources [9]. When compared to other sectors, the environmental effects related to universities are comparatively small, but the education sector has a prospect to play a transformative role in global change. Universities deliver poignant knowledge to all segments of society and act as anchors in the local and global communities as they are vanguard of scientific and technological advances in conducting research and educating professionals [10]. They are ideal testing grounds where sustainability solutions can be experimented and demonstrated, thus making them a Living Lab. It has already been identified that district- and campus-based initiatives can assist in sustainability and decarbonization at city-scale [11]. Thus, Universities can manifest sustainability — not only in theory, but in practice in everyday campus life. Moreover, a big agreement in the academic world is that universities should be heralds for climate friendly practices including carbon neutrality and sustainability on their campuses [12,13].

Over the years, some universities have achieved the carbon neutral status. The Leuphana University of Luneburg Germany reached carbon neutrality in 2014, seven years after setting its goal to become carbon neutral [14]. The university achieved its target by avoiding or offsetting emissions from business trips and vehicles, electricity, heating, water, and paper consumption. In 2016, Charles Sturt became the first Australian carbon neutral university [15]. It achieved the target by switching to renewable energy sources including roof-top solar and cogeneration, energy efficiency upgrades across existing buildings, and applying sustainable building principles and behavior change programs. In 2019, the University of San Francisco, USA, became carbon neutral, though the original target for becoming carbon neutral was set for 2050 [16]. The steps taken by the university included water conservation, switching to green cleaning supplies, installing micro turbines to yield power and heat on campus, and purchasing mission-driven carbon offsets. Some universities have pledged to become carbon neutral in a few years' time. For example: University of California, Davis, in the US, has committed to become carbon neutral by 2025 [17]; University of Bristol, UK, has set the target of 2030 to become carbon neutral [18]; University of Edinburgh, UK, has committed to become carbon neutral by 2040 [19], and University of Cape Town, South Africa, has committed to become carbon neutral by 2050 [20].

To become carbon neutral, organizations must first calculate their greenhouse gas emissions and then make an action plan for reducing emissions as much as possible and then purchase carbon offsets or carbon credits equivalent to the remaining emissions. This process results in emissions being offset and subsequently achieving carbon neutrality. For calculation of carbon footprint, the commonly used accounting tool is GHG Protocol, serving as a standard for measuring and reporting organizational level direct and indirect greenhouse gas emissions [21]. However, there are no internationally adopted guidelines available for higher education institutes [22]. The carbon footprint is measured in kilograms or tons of carbon dioxide or in terms of carbon dioxide equivalents when other greenhouse gases are also considered [23]. Many electronic calculators have been developed to quantify 
the carbon footprint and are publicly available [21]. Clabeaux et al., 2020 [24] evaluated the carbon footprint of Clemson University, USA, using the life cycle assessment approach, they calculated carbon footprint of the University for 2014, as around 95,000 metric tons $\mathrm{CO}_{2}$-equivalent. The major contributor of greenhouse gas emissions (41\%) was attributed to electricity generation. Udas et al. 2018 [25] presented a carbon neutrality case study of Greifswald University, Germany. For calculating energy related emissions, they acquired electricity and heating consumption data and based on standardized emission conversion factors, as devised by the German Federal Environment Agency, calculated the equivalent tons of $\mathrm{CO}_{2}$. For calculating travel related carbon emissions, total distance travelled using various transportation modes were calculated using travel order forms and converted into tons of equivalent $\mathrm{CO}_{2}$ using the respective conversion factors. Carbon footprint of Greifswald University was calculated to be 8985 tons $\mathrm{CO}_{2}$ per year. The study describes steady changes at institutional level, explains the strategies to decrease and offset the carbon emissions, and challenges in achieving carbon neutrality. Townsend and Barret, 2015 [7], used the Input-Output model for calculating the carbon footprint of University of Leeds, UK, which was found to be 161,819 tons of $\mathrm{eCO}_{2}$. Larsen et al., 2013 [26], used the Environmental Extended Input Output (EEIO) model to calculate the carbon footprint of the Norwegian University of Technology and Science. The total carbon footprint was calculated to be 92,000 tons of $\mathrm{eCO}_{2}$. Several studies as discussed above have been conducted in various countries, but no such study has been carried out for a university in Pakistan. As a contribution to efforts in making a campus located in a developing country carbon neutral and sustainable, this study evaluates NED University of Engineering and Technology, a public university located in Karachi, a cosmopolitan city of Pakistan. This paper presents how a university in a developing country may measure the carbon footprint and compare them with some standard. The aim of this study is to discuss carbon footprint calculation and various strategies planned and implemented by the university located in a developing country to embark on the mission of making the campus carbon neutral and sustainable by 2030 using a living lab model. To further highlight the impact of this baseline study, the overall aim has been elaborated in terms of following research questions:

- Carbon footprint measurement and calculation, including indicators selection, criteria, measurement and calculation method, validation examination, and limitation.

- Calculate and evaluate impact and effectiveness of various mitigation strategies in context of a higher education institution.

In future, this baseline study shall allow the project to address strategic and policy level questions. For example, this study will help in identifying various technical, social, and economic barriers in implementation of the mitigation measures, and identify challenges in scaling pilot interventions for creating greener and sustainable cities.

\section{Case Study-NED University}

NED University of Engineering and Technology is one of the oldest institutions in Pakistan for teaching and producing engineering graduates. It was established in 1921 during the British era as the Prince of Wales Engineering College and its status was upgraded over the time and finally attained University status in March 1977. Presently, the University is offering a total of 91 programs: 29 Bachelor's, 44 Master's, and 18 Ph.D. programs in the engineering, architecture, science, management, and other fields. The university has a current student population of more than 12,000 spread over its three campuses in Karachi. The University's main campus, which is the focus of this study, is spread over an area of 40 hectares that is located in a semi-arid coastal environment. Two months, April, and October, are the hottest when temperatures can be in the range of $40+{ }^{\circ} \mathrm{C}$ while winters are mild. The university has $118,266 \mathrm{~m}^{2}$ of building space covering around $30 \%$ of the total area. The computer labs, research centers, faculty offices, senior management offices, library, cafeteria, and some classes are air conditioned. Air conditioning units operate in months from April to October with an average use of $5 \mathrm{~h}$ per day except for computer laboratories, server rooms, and other essential places where $24 / 7$ cooling is needed. Heating facilities are 
not required as winters are mild. The university has 48 weeks of academic calendar that encompasses spring (March-July), fall (October-February), and summer (August-September) sessions. Summer sessions have lower carbon footprint as compared to spring and fall sessions as the overall campus activities are reduced and very few students register $(10 \%)$ in it. The Directorate of Planning and Development is responsible for strengthening the university's infrastructure including new buildings. The university's main library is being renovated/retrofitted so that it can meet Leadership in Energy and Environmental Design (LEED) standards.

NED University is striving to manifest sustainability not only in theory, but in practice by making the everyday campus life "A Living Lab" model. This model brings the university's management team into quicker discourse with faculty and students to solve real-world problems through empirical training and learning, research, development, and consultancy projects that may be conducted within the university or with external partners [12]. In 2017, a steering committee comprising of university leadership, senior faculty from relevant departments (Architecture and Planning, Civil Engineering, Computer and Information Systems Engineering, Electrical Engineering, Environmental Engineering, Mechanical Engineering, Polymer and Petrochemical Engineering, Urban and Infrastructure Engineering) and officers of various non-teaching departments (Directorate of Works and Services, and Controller Student Affairs) was formed to transform NED University into a carbon neutral and sustainable campus as shown in Figure 1. This committee is being led by the University's Vice Chancellor. The university has signed the Talloires Declaration and is the first university in Pakistan to sign this declaration indicating the university's commitment to environmental sustainability. The steering committee has already devised and implemented a few measures, such as estimating the institute's carbon footprint, dissemination of information via outreach activities, tree plantation campaign, establishment of urban forests, and water recycling. An annual sustainability report has also been published since 2018.

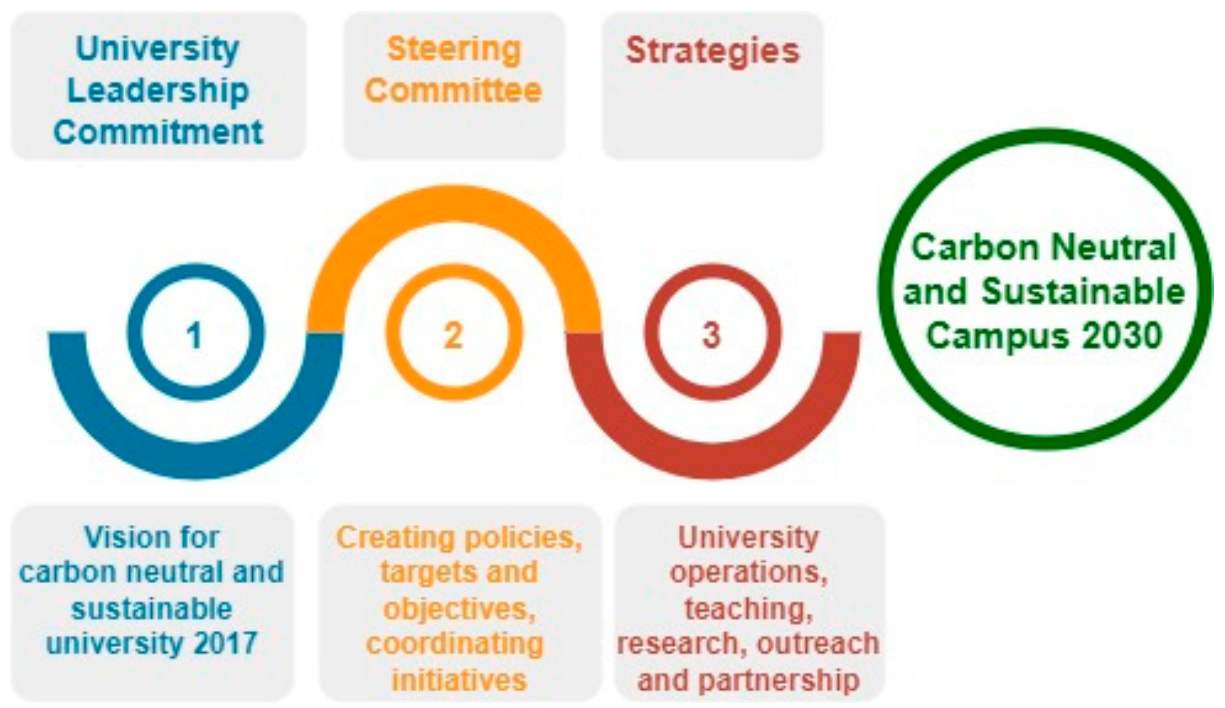

Figure 1. Institutional framework of NED University for achieving carbon neutrality and sustainability.

\section{Approach}

\subsection{Campus Carbon Footprint Estimation}

In 2017, the carbon footprint of NED University main campus was calculated using the Clean Air Cool Planet (CA-CP) Carbon Calculator. The Campus Carbon Calculator (CCC) was originally developed by the former non-profit Clean Air-Cool Planet and the Sustainability Institute at University of New Hampshire (UNH), USA. Thousands of institutions across USA and abroad have used this calculator to track their institutional greenhouse gas emissions. The carbon footprint is rooted in the indicators of global warming potentials 
which represents the quantities of greenhouse gases (GHG) that contribute to global warming. It gives estimates of $\mathrm{CO}_{2}$-equivalent weight of the total $\mathrm{GHG}$ emissions produced by campus activities for 3 scopes which are shown in Table 2. The method used in this study takes into account the non- $\mathrm{CO}_{2}$ emissions $\left(\mathrm{CH}_{4}, \mathrm{~N}_{2} \mathrm{O}\right)$ also relevant to various campus activities which are discussed below in Section 3.3. The pertinent data (energy production on-campus, electricity purchased, transportation, waste, agriculture, and refrigerants) are input into the Excel-based calculator that changes different emissions sources from their original measurements into $\mathrm{CO}_{2}$ produced by multiplying them with an emission factor. This factor is a unique value for scaling emissions to activity data in terms of a standard rate of emissions per unit of activity (e.g., grams of carbon dioxide produced per barrel of fossil fuel spent). For instance, electricity is measured in kilowatt hours (kWh) used and would be converted to metric tons equivalent of $\mathrm{CO}_{2}$ produced. According to the EPA, $1 \mathrm{kWh}$ of electricity used will produce 0.0007 metric tons of $\mathrm{CO}_{2}$ [27]. This gives GHG $\left(\mathrm{CO}_{2}, \mathrm{CH}_{4}, \mathrm{~N}_{2} \mathrm{O}\right)$ values per source which are subsequently converted into carbon dioxide equivalents and used to compare the emissions from various greenhouse gases based upon their global warming potential (GWP). GWPs are calculated as the ratio of the radiative forcing that would result from the emissions of one kilogram of a greenhouse gas to that from emission of one kilogram of carbon dioxide over a time period (usually 100 years). The results of this study were validated by industrial experts.

For creating the inventory, three boundaries were considered: organizational, operational, and temporal. Inventory data were gathered from relevant university departments. The organizational and operational data were entered in the input data sheet. The organizational data included information on budget, campus population, physical size while other data included information of purchased electricity; on-campus cogeneration plant; stationary sources of emissions; university fleet; travel; commuting; agriculture; solid waste; paper; refrigeration; and other chemicals. When relevant data are entered in the spreadsheet, the calculator automatically takes those numbers and calculates emission results in $\mathrm{MT}$ eCO2 as discussed above. Boundaries of inventory are explained as follows:

\subsection{Organizational Boundaries}

Organizational boundaries are top level boundary. It states whether emissions are measured for entire campus or any specific portion/department. Depending on this boundary, the facilities and buildings that are to be included into the analysis are determined. For this study NED University, main campus was selected as the organizational boundary.

\subsection{Operational Boundaries}

The operational boundaries identify emission sources to be included in the inventory. The GHG protocol uses scopes, in which all emission sources are categorized into three scopes. Scope 1 emissions include direct emissions from sources that are owned or controlled by university campus; Scope 2 emissions consist of upstream emissions from the generation of purchased electricity; and Scope 3 emissions are indirect emissions from sources owned or controlled by another entity. Description of each scope for our case study is explained as below:

- $\quad$ Scope 1 On-Campus Emissions: Scope 1 emissions cover greenhouse gas emissions produced directly from sources that are owned or controlled by NED University. In this component, emissions were analyzed from the operational phase for electricity generation, university vehicles, refrigerants and chemicals, fertilizer application, and treatment of wastewater. On-Campus stationary emissions include all stationary sources of emissions on campus. For electricity generation, the calculator has source options of Natural Gas, LPG (Propane), Coal (Steam Coal), Incinerated Waste, Wood Chips, Wood Pellets, Grass Pellets, Residual Bio-Heat, Distillate Bio-Heat, Attributable Solar-Electric, Attributable Solar-Thermal, and Attributable Wind. While for university fleet that contribute to direct transportation emissions information needed to calculate emissions type of fleet includes Gasoline Fleet, Diesel Fleet, Natural Gas Fleet, 
E85 Fleet, B5 Fleet, B20 Fleet, B100, Hydrogen, Other Fleet Fuel, and Electric Fleet. The refrigerants information includes HFC-134a, R-404a, HCFC-22, HCFE-235da2, and HG-10. Other: For fertilizer, organic or synthetic type info is needed.

- Scope 2 Off-Campus Emissions: The info required by the calculator to calculate off-campus emissions is that of electricity purchased off-campus in $\mathrm{kWh}$. Scope 2 emissions comprised of upstream emissions from the generation of electricity that is purchased from power generation company, i.e., K-Electric (KE) in this case.

- Scope 3 Indirect Emissions: Scope 3 emissions includes all indirect emissions that come from sources owned or controlled by outside entities, excluding Scope 2 emissions. Scope 3 emissions consists of university related travel of staff and students national and international, paper usage, waste and recycling transportation, wastewater treatment chemicals, and water treatment. The commute of students and staff members to and from the campus was estimated considering weighted average of distances travelled by the campus population from across the city and various modes of transport used. The international travel component and local travel to and from various parts of the country was not included in the calculations as it is negligible. The carbon calculator requires information related to faculty/staff and student commutation. It covers various modes including Carbon-free, Automobile, Bus, Light Rail, Commuter Rail. Solid waste info covers Incinerated Waste (Mass Burned, Refuse Derived Fuel) or/and Landfilled Waste (No $\mathrm{CH}_{4}$ Recovery, $\mathrm{CH}_{4}$ Recovery and Flaring, $\mathrm{CH}_{4}$ Recovery, and Electric Generation). While for Wastewater treatment info required is septic, centralized treatment (aerobic or anaerobic). Paper information required include fresh sheet or uncoated $(0 \%, 25 \%$, $50 \%, 75 \%$, or $100 \%$ recycled).

\subsection{Temporal Boundaries}

The last boundary is the temporal boundary. The calculator uses fiscal years. For this study, fiscal year 2017 was considered. All the carbon footprint calculations were performed based on data gathered in 2017, and they are the baseline for the university.

\section{Socially Inclusive and Advocacy Framework}

University steering committee adopted mixed-mode methodology to achieve the long-term goal and become carbon neutral in near future. Three key interventions were identified: planting trees, establishing urban forests, and water recycling as quantitative measures, whereas behavior change through outreach activities via inclusion of university community and other stakeholders as qualitative measures.

\subsection{Tree Plantation and Urban Forest Establishment}

Karachi is a mega coastal city with more than 20 million inhabitants, and where this university is located is facing serious environmental degradation problems. The city, in recent years, has also experienced episodes of heat waves and flooding. Karachi's physical/natural environment and resources are already stressed because of poor planning and governance. Rapid urbanization and associated human activities have disturbed the city's ecological balance. According to findings of a study in 2008, total vegetation cover in Karachi was roughly $7 \%$ of the total land area at that time. However, the minimal green spaces are also continuously disappearing as a recent study shows that vegetation cover in Karachi has decreased by 6.82\% since 1998 [28]. As universities play an important role in inculcating sustainability principles in the young minds and imparting environmental education (pro-ecological), the university came up with the idea of planting more trees on campus including urban forest concept implementation as part of the living lab concept. The university student population bears the potential of becoming the leaders in the future to drive and lead towards a sustainable and environmentally friendly economy and society. Their awareness and sensitization towards developing pro-ecological solutions will enable them to play a sustainable and responsible role in addressing the environmental challenges effectively. 
A tree census was carried out in 2017 to learn about the number of trees on campus. Moreover, to increase number of trees a strategy was developed by the steering committee. To maximize plantation of trees in a land constraint urban area, the Miyawaki method was adopted for plantation of urban forests on campus. The concept of urban forest is to generate a very dense cover of trees on an open space in an urban area where land availability is very difficult. The urban forest acts as an exclusive ecosystem that offer a wide range of benefits. Native plant species are planted, conventional pesticides or fertilizers are not used, and the forests are watered only in the early years of establishment [29]. An urban forest can be created using the Miyawaki Method, invented by Dr. Akira Miyawaki in Yokohama, Japan, in the 1970s. The trees grow 10 times faster than conventional plantations, are 100 times more bio-diverse and have 30 times greener surface area. Entire development process is $100 \%$ organic with no addition of chemicals and pesticides. They retain water, thus assist in recharging the ground water table, attract more birds and insects, produce native fruits, and improve air quality. They have 30 times more $\mathrm{CO}_{2}$ absorption capacity and 30 times better noise, and dust reduction ability, than the conventional tree plantation. Another important aspect of urban forest is that after two to three years of plantation, they become self-sufficient and do not depend on any external maintenance and become self-sustaining. The urban forest development activity has been carried out by involving community as community engagement leads to valued capacity building [30].

Table 1. Carbon footprints of universities located in various geographic locations.

\begin{tabular}{|c|c|c|c|c|c|}
\hline University Name & Location & $\begin{array}{c}\text { Student } \\
\text { Population }\end{array}$ & $\begin{array}{c}\text { Total Carbon } \\
\text { Footprint (MT e } \\
\left.\mathrm{CO}_{2}\right)\end{array}$ & $\begin{array}{c}\text { Carbon Footprint } \\
\text { per Student (MT e } \\
\left.\mathrm{CO}_{2}\right)\end{array}$ & Reference \\
\hline $\begin{array}{l}\text { University of } \\
\text { Leeds }\end{array}$ & UK & 30,761 & 161,819 & 5.3 & $\begin{array}{l}\text { Townsend and } \\
\text { Barrett, } 2015 \text { [7] }\end{array}$ \\
\hline $\begin{array}{l}\text { Clemson } \\
\text { University }\end{array}$ & USA & 21,857 & 95,418 & 4.4 & $\begin{array}{l}\text { Clabeaux et al., } \\
2020 \\
{[24]}\end{array}$ \\
\hline $\begin{array}{l}\text { Norwegian } \\
\text { University of } \\
\text { Technology and } \\
\text { Science }\end{array}$ & Norway & 20,000 & 92,000 & 4.6 & $\begin{array}{c}\text { Larsen et al., } 2013 \\
\text { [26] }\end{array}$ \\
\hline Tongji University & China & 47,000 & - & 3.8 & $\begin{array}{c}\text { Li et al., } 2015 \\
{[34]}\end{array}$ \\
\hline $\begin{array}{l}\text { University of Cape } \\
\text { Town }\end{array}$ & South Africa & 21,175 & 84,926 & 4.0 & $\begin{array}{c}\text { Letete et al., } 2012 \\
\text { [32] }\end{array}$ \\
\hline $\begin{array}{l}\text { De Montfort } \\
\text { University }\end{array}$ & UK & 21,585 & 51,080 & 2.4 & $\begin{array}{c}\text { Ozawa-Meida } \\
\text { et al., } 2013 \\
{[31]}\end{array}$ \\
\hline $\begin{array}{l}\text { University of } \\
\text { Illinois at Chicago }\end{array}$ & USA & 25,125 & 275,000 & 10.9 & $\begin{array}{c}\text { Klein-Banai et al., } \\
2010 \\
{[33]}\end{array}$ \\
\hline NED University & Pakistan & 12,000 & 21,500 & 1.79 & This study \\
\hline
\end{tabular}

\subsection{Water Recycling}

The cosmopolitan city of Karachi where this university is located has a semi-arid environment. The city is expanding at a very fast pace and the gap between water supply and demand is continuously swelling. The increase in water demand is stressing the already scarce water resources. Very few water recycling projects have been implemented in the city. Therefore, considering wastewater as a resource and preventing water pollution, the university management planned and implemented a water recycling scheme as part of the living lab concept. For this purpose, the wastewater collection system was improved, and all campus wastewater was conveyed to a wastewater treatment plant via a properly designed sewer system. This treatment plant treats the campus wastewater, and the treated wastewater is subsequently used for landscape irrigation of the campus. 


\subsection{Vegetation Cover Monitoring}

The increase in campus vegetation cover is monitored and cross verified scientifically using the image analysis technique. Vegetation cover in the NED University main campus for the last 13 years were analyzed. Figure 2 depicts methodology for vegetation cover analysis. Images of NED University for the years 2008 (before installation of wastewater treatment facility), 2017, and 2021 (after installation of wastewater treatment facility) were acquired from Google Earth Pro. The images were preprocessed to adjust brightness and contrast. The region of interest (ROI), i.e., NED University boundary in our case was delineated. Vegetation area being green in color was identified by applying hard color thresholding. The resultant image after the application of hard thresholding is a black and white image where the black portion indicates vegetation area and white portion indicates non-vegetated area. The area of black pixels region was then calculated to find the vegetated area and presented in $\mathrm{km}^{2}$. It is to be noted that the pixel size of all images is the same, which is $4800 \times 2360$ pixels, for the total area of NED University which is $0.40 \mathrm{~km}^{2}$.

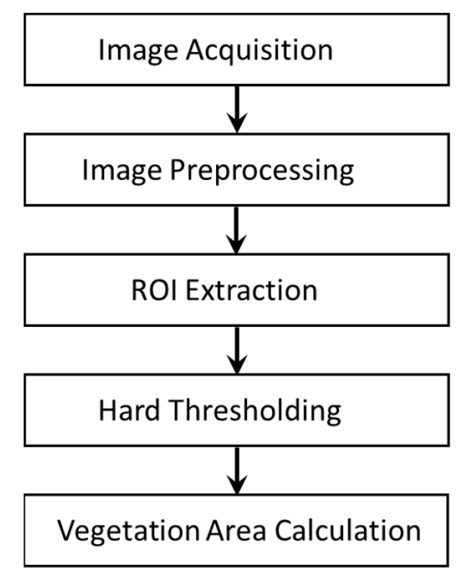

Figure 2. Methodology for vegetation cover analysis (ROI; region of interest).

\subsection{Outreach Activities}

The university has organized several outreach activities including orientation seminars, student mobility project, conference organization, and behavioral change activity.

\section{Results and Comparison}

The total carbon footprint calculated for NED University main campus in 2017 was estimated to be 21,500 metric tons (MT) of equivalent $\mathrm{CO}_{2}\left(\mathrm{eCO}_{2}\right)$ including both direct and indirect emissions. This included Scope 1, 2, and 3 emissions, which were 1560, 1485, and 18,400 metric tons $\mathrm{eCO}_{2}$, respectively. The emissions estimated from each source and their overall contributions are illustrated in Table 2.

The estimated carbon footprint of NED University is lower as compared to estimations of higher education institutions located in different parts of the developed world: University of Sydney, Australia, 20,000 metric tons $\mathrm{eCO}_{2}$; De Montfort University, UK, 51,080 metric tons $\mathrm{eCO}_{2}$; University of Illinois at Chicago, USA, 275,000 metric tons $\mathrm{eCO}_{2}$, as tabulated in Table 1. The carbon footprint per student $\left(\mathrm{MT} \mathrm{eCO}_{2}\right)$ is highest for University of Illinois at Chicago, USA, which is 10.9 while lowest is for De Montfort University, UK, which is 2.4, as reported in international literature. Universities located in the developed world have higher per capita emission values than NED University, i.e., located in the developing world. The carbon footprint per student for this study is low $1.79 \mathrm{MT}$ e $\mathrm{CO}_{2}$ as compared to values reported in literature. The possible reason for high carbon footprint value per student in different countries of the world is the high heating requirements in those regions plus the affluent living style in the developed world that contributes to more carbon emissions. The low value of $1.79 \mathrm{MT}$ e $\mathrm{CO}_{2}$ in this study is due several reasons including no heating requirement because of mild winter weather in Karachi; use of occasional air-conditioning 
facilities during summers and moderate living style as compared to the developed world. However, to the best of our knowledge there are no internationally adopted guidelines available for calculation of carbon footprints for higher education institutes.

Universities have various population sizes, building areas, emission sources and different universities use different methods for calculation of carbon footprint. Therefore, comparing carbon footprints of universities is challenging.

It is clear from Table 2 that for NED University scope 3 has the largest share and is 85.6\% of total carbon footprint. Larsen et al., 2013 [26] and Ozawa-Meida et al., 2013 [31] calculated the carbon footprint of university located in the developed world and also reported scope 3 contributed highest share $81 \%$ and $79 \%$ of total carbon footprint, for Norwegian University of Technology and Science and De Montfort University, UK, respectively. However, the carbon footprint reported by Letete et al., 2012 [32] and Klein-Banai et al., 2010 [33] for University of Illinois at Chicago, USA, and University of Cape Town, South Africa, showed that scope 3 contributed to $19 \%$ for both the universities. It is therefore challenging to compare carbon footprints of universities because the sources accounted for are not consistent. Robinson et al., 2018 [22] has stated apprehension that institutions may be depicted unfairly due to disparity in indirect emissions reporting.

Table 2. Distribution of carbon emissions under the scope and activity heads.

\begin{tabular}{|c|c|c|c|c|}
\hline Scope & Input Data & $\begin{array}{l}\text { Estimated } \\
\text { Amount }\end{array}$ & $\mathrm{MT} \mathrm{eCO}_{2}$ & $\begin{array}{l}\text { Total MT eCO } \\
\text { Carbon } \\
\text { Footprint }(\%)\end{array}$ \\
\hline \multirow{5}{*}{ Scope 1} & $\begin{array}{l}\text { Diesel for power } \\
\text { generation }\end{array}$ & 1500 Gallons & 13 & \multirow{5}{*}{$\approx 1600(7.4 \%)$} \\
\hline & Natural gas & 22,000 MMBtu & 1100 & \\
\hline & $\begin{array}{l}\text { Diesel for } \\
\text { university buses }\end{array}$ & 21,000 Gallons & 300 & \\
\hline & Refrigerants & $250 \mathrm{lbs}$ & 200 & \\
\hline & $\begin{array}{l}\text { Organic } \\
\text { fertilizers }\end{array}$ & $6250 \mathrm{lbs}$ & 1 & \\
\hline Scope 2 & $\begin{array}{l}\text { Purchased } \\
\text { electricity }\end{array}$ & $3655 \mathrm{MWh}$ & 1500 & $\approx 1500(7 \%)$ \\
\hline \multirow{3}{*}{ Scope 3} & $\begin{array}{l}\text { Student and staff } \\
\text { commute }\end{array}$ & $14.8 \mathrm{~km}$ one-way & 18,100 & \multirow{3}{*}{$\approx 18,400(85.6 \%)$} \\
\hline & Solid waste & 10 tons & 30 & \\
\hline & Paper & 100 tons & 270 & \\
\hline
\end{tabular}

\section{Discussion}

\subsection{University Level Initiatives Outcome (Quantitative)}

Tree Plantation and Urban Forest Establishment: Tree plantation helps in balancing carbon emissions. A tree census conducted in 2017, revealed that there are 6539 fully grown trees on campus. To increase number of trees in a small space rapidly, urban forests were developed on the campus. Tree selection is an important part of urban forest development as tree planting combats biodiversity loss [35]. The World-Wide Fund for Nature-Pakistan's natural resource manager has reported that out of 200 species of birds listed in late 1980s by an ornithologist Dr Thomas Jones Roberts, nearly 50 per cent are no longer found in Karachi. All trees selected for the urban forest were native fruit trees as fruit tree increase functional and phylogenetic diversity of birds [34]. To increase number of trees in a small space at a faster rate with biodiversity enhancement, five Miyawaki forests covering an area of $168 \mathrm{~m}^{2}$ with 540 fruit trees were established on the campus. The first urban forest at the campus was developed in July 2019 and is now thriving as can be seen in Figure 3. Students and industry both were involved in the development of these forests. Participation of students in developing pro-ecological solutions empower them on campus to become future leaders who will use their knowledge to create sustainable impact in 
service to the world. For public involvement and sensitization of community a dedicated website was developed, details of the urban forests can be accessed through the website. The website also gives information on the amount of $\mathrm{CO}_{2}$ sequestered by these forests in real-time (https:/ / co2smart.neduet.edu.pk/e-club/index-urban-forest.html, accessed on 15 December 2021). The amount of carbon dioxide sequestered is calculated based on an algorithm that has been developed based on the "Method for Calculating Carbon Sequestration by Trees in Urban and Suburban Settings; Voluntary Reporting of Greenhouse Gases" published by the US Department of Energy. The calculation is made based on several attributes including species characteristics, tree age, survival factor, number of surviving trees, and annual sequestration rate.

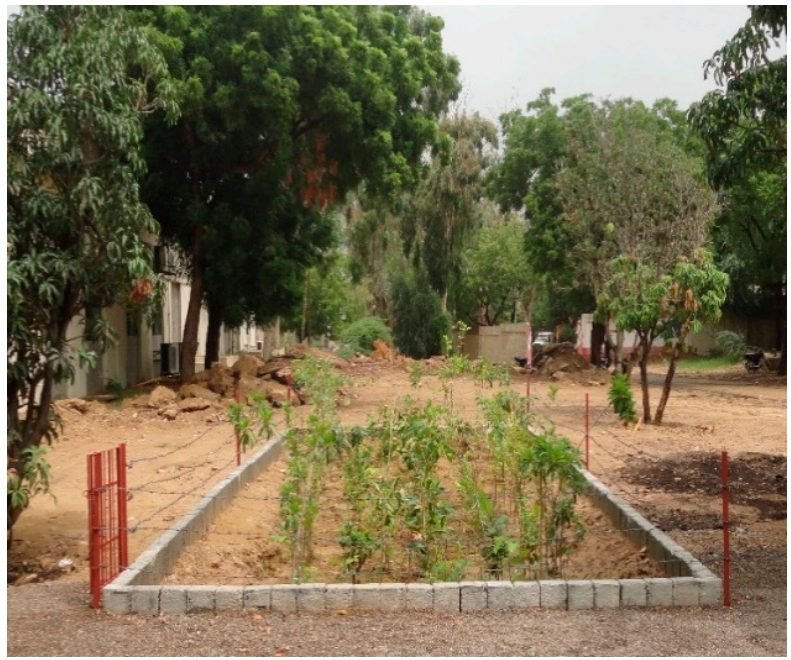

(a)

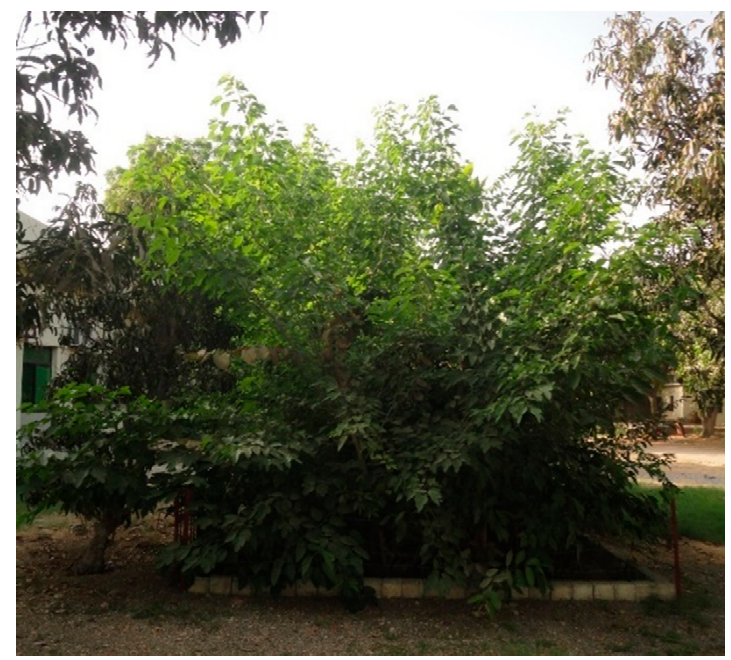

(b)

Figure 3. First urban forest established at NED University (a) At time of establishment, July 2019 (b) Dense vegetation after short duration of 20 months, March 2021.

Applying the living lab model, the university has now reached out to external organizations, such as local government and industries, as a measure to connect with a broader stakeholder cluster and help establish urban forests city wide. Establishment of five urban forests in different polluted traffic corridors of the city are currently under development.

Water Recycling: Nearly $90 \mathrm{~m}^{3} / \mathrm{d}$ of wastewater is treated in the main wastewater treatment plant constructed on the campus. The wastewater from the campus is first collected in a wet well from where it is pumped to the wastewater treatment plant. The treatment steps include screening, grit removal, primary settling, biological treatment, secondary settling, and disinfection. To enhance efficiency of the system, a nature-based pond treatment system is also part of treatment train. The biological treatment is based on the suspended growth reactor, i.e., activated sludge process. The treatment plant is designed for influent wastewater having 5-day biochemical oxygen demand $200 \mathrm{mg} / \mathrm{L}$; chemical oxygen demand $375 \mathrm{mg} / \mathrm{L}$; suspended solids $150 \mathrm{mg} / \mathrm{L}$; and ammonia nitrogen of $40 \mathrm{mg} / \mathrm{L}$. The treated wastewater from this plant is used to irrigate the university's landscaped areas. Moreover, greywater recycling facilities have also been developed for treating greywater from the campus mosque and library facilities. All treated water is tested to check compliance with reuse standards. This measure taken by the university saves the precious and scarce fresh water supply and prevents water pollution that would have been caused if untreated wastewater was discharged from the campus. The provision of wastewater treatment facilities saves an estimated amount of $33,580 \mathrm{~m}^{3}$ of fresh water annually and has assisted in increase in the campus green cover.

Vegetation Cover: Changes in vegetation cover because of above activities can be seen in Figure 4. Figure 4 represent raw and processed images of 2008, 2017, and 2021. It is evident that the vegetation area has increased from $0.11 \mathrm{~km}^{2}$ in 2008 when there was no 
water recycling scheme to $0.23 \mathrm{~km}^{2}$ in 2021 when recycling was practiced. It also shows the wastewater treatment and recycling has been successful and resulted in substantial increase in campus vegetation cover; 31\% increase between 2008 and 2017; 109\% increase from 2008 to 2021 . The water recycling has contributed to the sustainability of the environment by using wastewater as a resource for greening the campus.

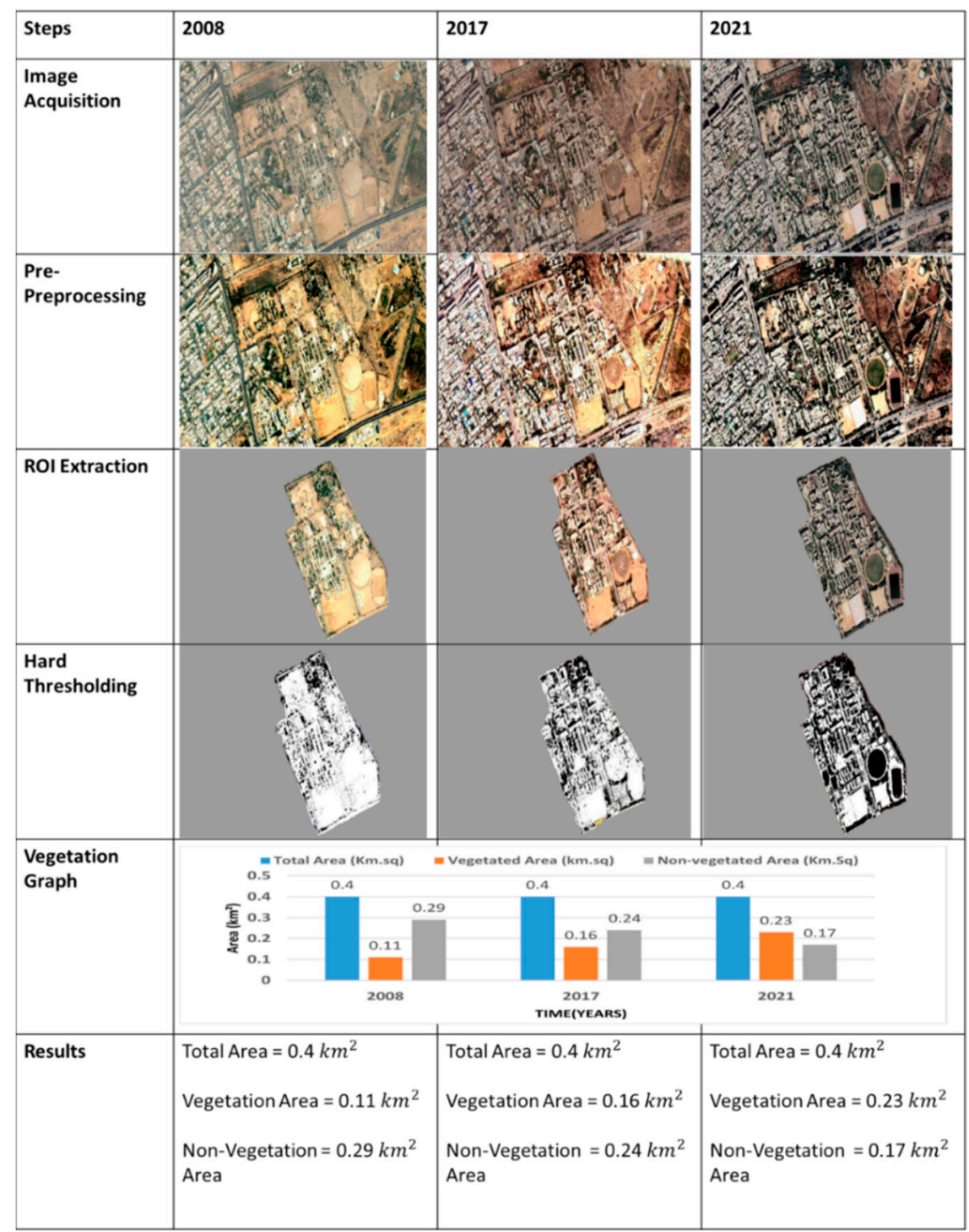

Figure 4. Raw and processed images of NED university main campus for estimating vegetation cover.

\subsection{University Level Initiatives Outcome (Qualitative)}

Outreach Activities: The outcomes of outreach activities documented by different organizations and educational institutions shows that target participants are very much interested in the issues related to environment, but due to absence of issue-specific knowledge and awareness, they hesitate to act [36]. Therefore, the outreach activities planned and executed by NED University focuses on educating the pertinent participants to fully benefit the participants of different outreach activities. Various events are organized by the academic, administrative, and student bodies of NED University addressing and highlighting environment and sustainability issues including annual tree plantation campaign. The Green Society of university actively promotes recycle, reuse, and reduce campaign to reduce the waste generation in the university as well as encourages the minimal use of paper and plastic products at the campus and in daily lives among the students and the staff members of the University. 
A project titled "Thar Karachi student mobility campaign for reducing carbon footprint" was developed and implemented. The project was carried out in collaboration with industry and non-government organization as partners. School students from Thar region and Karachi were selected, students spent time with the local students and their families where they learnt about their life, ethos, and societal and environmental issues. A seminar and interactive session were organized to educate the students about anthropogenic release of greenhouse gases in the atmosphere and its effect on climate. Students from both sides also planted trees at selected locations with their names on them and a tracking number. The students are now able to track the status of their planted tree in real-time (Figure 5) via smartphones and online along with the amount of $\mathrm{CO}_{2}$ sequestered through a dedicated website developed by the university (https://tksm.co2smart.neduet.edu.pk/, accessed on 31 December 2021).

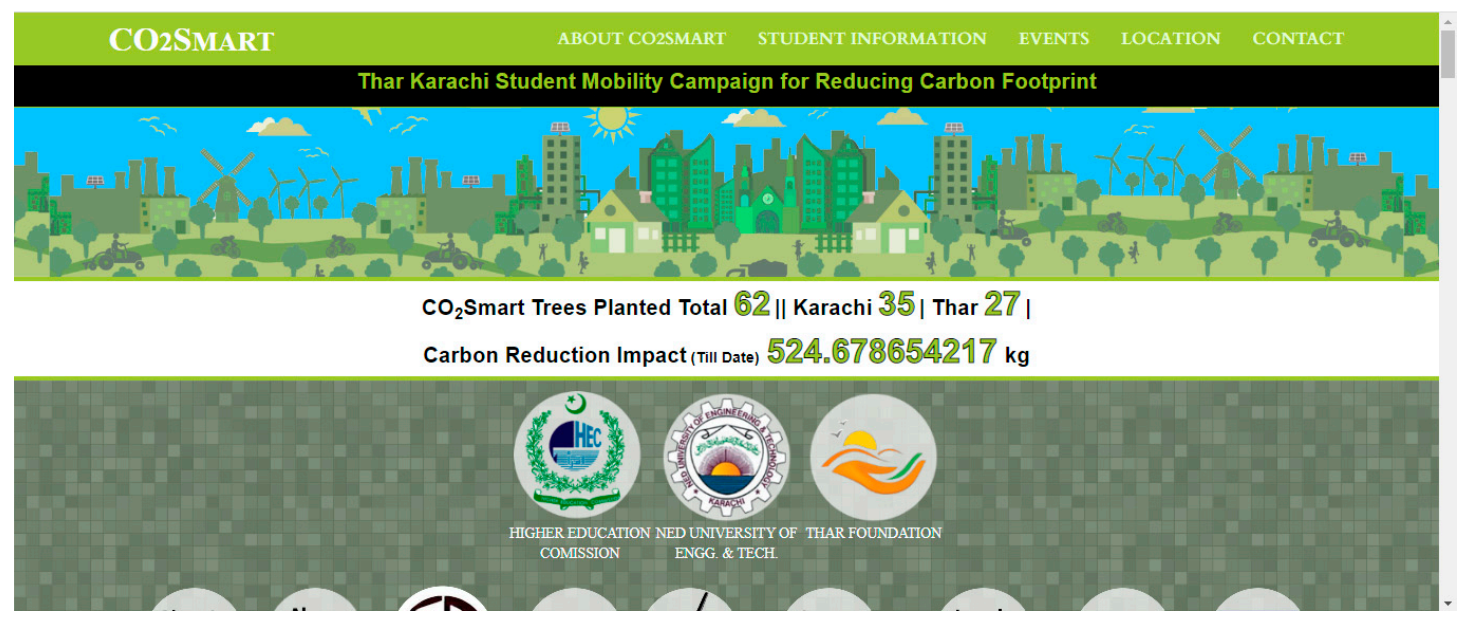

Figure 5. Glimpse of main page of the website showing real-time online monitoring of $\mathrm{CO}_{2}$ sequestered by tree plantation campaign.

One of the main challenges that HEIs face in the realm of sustainability promotion and implementation is lack of support by students, faculty members, and management [37]. Outreach activities including organization of conferences involving stakeholder participation can play a critical role in overcoming the obstructions to implement sustainability and sustainable development initiatives within HEIs. The organization of international conferences are an important approach for universities to justify their part in meeting global environmental mandates [38]. In November 2018, NED University of Engineering and Technology in partnership with Institute of Engineers, Pakistan, Karachi, hosted a two-day International Conference on Carbon Neutral Built Environment. This event provided an opportunity for engagement and exchange of thoughts and experiences regarding the concepts of climate change, sustainability, and carbon neutrality. Local participants including students as well as international participants from Australia and the UK shared their research and success stories for making their institutes carbon neutral and sustainable. Furthermore, in November 2019, a seminar on carbon footprint was organized by NED University of Engineering and Technology. Industrial experts and university leadership along with departmental chairs, heads of various non-teaching departments, and students attended this seminar. Initiatives taken by NED University to reduce its carbon footprint, for achieving the carbon neutrality target, and the journey of transforming the university into a sustainable campus by minimizing paper usage and waste, efficient utilization of energy and resources were highlighted by industrial professionals and members of the steering committee. In November 2021, a survey was conducted in which paper usage in each department was assessed. Department wise paper usage data were collected from the Directorate of Works and Services, which is responsible for paper purchase and supply to 
all departments. The survey showed that there has been $35 \%$ reduction in overall paper usage at the campus.

\section{Decarbonization Trends of NED University}

The university under the guidance of the steering committee has already started taking actions for making the campus sustainable and carbon neutral by 2030. Working on developing learning material, courses, programs, and faculty addressing climate change and sustainability challenges has been initiated. The university's total power requirement is estimated to be $3 \mathrm{MW}$. Work to transform campus energy consumption from hydrocarbon reliance to renewables is underway and presently $7 \%$ of power demand is met by renewables. A project to switch to $100 \%$ reliance on renewables is under progress. Moreover, installation of energy efficient appliances like LED lights and smart fans indigenously developed at the university would also assist in carbon mitigation. Creating a culture of using technology to change behaviors towards responsible consumption, sustainable waste management and development of course materials is also being implemented. The university also plans to further boost developing R\&D workforce capable of representing Pakistan in successfully meeting global climate change, environmental, and sustainability challenges.

Average distance traveled by all staff/faculty/students for their one-way commute to the campus is estimated to be approximately $14.2 \mathrm{~km}$ (9.2 miles). While average distance walked by all staff/faculty/students for their commutation within the campus is around $0.74 \mathrm{~km}$ ( $0.46 \mathrm{miles})$. The university management introduced a behavioral change measure. Every week on Fridays, all fossil fuel-based transportation modes are not allowed to enter the campus and this day is declared as healthy Friday. Based on 48 weeks academic calendar estimated emission savings due to this behavioral change measure is estimated to be approximately $4.5 \mathrm{MT} \mathrm{eCO}$ per week and $180.6 \mathrm{MT} \mathrm{eCO}_{2}$ per year. The social and economic impacts of various activities adopted by the university are presented in Table 3 .

Table 3. Social and Economic Impacts of Carbon Management Measures.

\begin{tabular}{|c|c|}
\hline Beneficiary & Social and Economic Impacts \\
\hline Government official and Policy maker & $\begin{array}{l}\text { Benchmarking of available efforts and initiatives for } \\
\text { inclusion and implementation at national level } \\
\text { agenda }\end{array}$ \\
\hline Industry and Corporate Sector & $\begin{array}{l}\text { Technology transfer for environmentally friendly } \\
\text { solutions }\end{array}$ \\
\hline University Leadership & $\begin{array}{l}\text { Improved national and global visibility, and inclusion } \\
\text { Carbon credits } \\
\text { Improved health and well being }\end{array}$ \\
\hline Researchers & Promotion of relevant research \\
\hline Faculty and Staff & $\begin{array}{l}\text { Dissemination, addition to curriculum and learning } \\
\text { content related to climate change and sustainability }\end{array}$ \\
\hline General Visitors & $\begin{array}{l}\text { Advocacy for ideas implementable at low cost and } \\
\text { domestic level }\end{array}$ \\
\hline Student & $\begin{array}{l}\text { Awareness and advocacy for climate change } \\
\text { initiatives } \\
\text { Ideas for undergrad and postgrad projects } \\
\text { Improvement in affective domains }\end{array}$ \\
\hline
\end{tabular}

Table 4 represents the decarbonization trends based on different approaches planned and implemented by the university steering capacity. Scope 3 emission sources that are the largest carbon emission contributor are not usually reported by organizations, however, this study reports scope 3 emissions also. The main strategies selected by NED university for carbon mitigation are plantation inside and outside campus and switching over to renewables for fulfilling power requirements. Under the scope 1 caption, diesel use, which is used in 27 standby power generators, has started to be reduced as solarization has started, 
and it is planned that by 2030 diesel requirement for power generation will be eliminated. Introduction of electric buses in different phases, replacing the diesel operated university buses, has been initiated and will reduce the carbon emissions progressively. With the university's planned strategies, it is anticipated that by 2030 NED university will become carbon neutral (Table 4) covering scopes 1 and 2.

Table 4. Measured carbon footprint and estimated decarbonization trends for NED University.

\begin{tabular}{|c|c|c|c|c|c|}
\hline \multirow{2}{*}{ Sources } & \multicolumn{5}{|c|}{ Carbon Emissions $\mathrm{MT}$ eCO } \\
\hline & 2017 & 2021 & 2024 & 2027 & 2030 \\
\hline & \multicolumn{2}{|l|}{ Measured } & \multicolumn{3}{|l|}{ Forecasted } \\
\hline \multicolumn{6}{|l|}{ Scope 1} \\
\hline Diesel for power generation (Gallons) & (1500) 13 & (900) 8 & $(600) 5$ & (200) 2 & (0) 0 \\
\hline Natural gas (MMBtu) & $(22,000) 1100$ & $(17,500) 875$ & $(13,000) 650$ & (9000) 450 & (6500) 325 \\
\hline Diesel for university buses (Gallons) & $(21,000) 300$ & $(17,500) 250$ & $(12,000) 171$ & (8000) 114 & (5000) 71 \\
\hline Refrigerants (lbs) & (250) 200 & (250) 200 & (250) 200 & (250) 200 & (250) 200 \\
\hline Organic fertilizers (lbs) & $(6250) 1$ & $(6250) 1$ & $(6250) 1$ & $(6250) 1$ & $(6250) 1$ \\
\hline \multicolumn{6}{|l|}{ Scope 2} \\
\hline Purchased electricity (kWh) & (3655) 1500 & (2800) 1149 & (2500) 1026 & (2200) 903 & ) 657 \\
\hline \multicolumn{6}{|l|}{ Scope 3} \\
\hline Student and staff commute $(\mathrm{km})$ & (14.8) 18,100 & (12) 14,676 & (10) 12,230 & (8) 9784 & (5) 6115 \\
\hline Solid waste (tons) & (10) 13 & (10.5) 13 & (11) 14 & (12) 14 & (12.5) 15 \\
\hline Paper (tons) & (100) 270 & (65) 176 & (60) 162 & (55) 149 & (50) 135 \\
\hline Total Carbon Emissions & $\mathrm{MT} \mathrm{eCO}_{2}$ & & & & \\
\hline Scope 1 and 2 & 3114 & 2483 & 2054 & 1670 & 1255 \\
\hline Scope $1,2 \& 3$ & 21,497 & 17,347 & 14,459 & 11,617 & 7520 \\
\hline \multirow{2}{*}{ Mitigation Measures } & \multicolumn{5}{|l|}{$\mathrm{MT} \mathrm{eCO} 2$} \\
\hline & 2017 & 2021 & 2024 & 2027 & 2030 \\
\hline Plantation (Number) & $(6500)$ & $(8700)$ & (1850) & $(26,000)$ & $(57,000)$ \\
\hline (in and outside campus) & -143 & -191 & -407 & -572 & -1255 \\
\hline Net Carbon Emissions & \multicolumn{5}{|l|}{$\mathrm{MT} \mathrm{eCO} 2$} \\
\hline Scope 1 and 2 & 2971 & 2292 & 1647 & 1098 & 0 \\
\hline Scope 1, 2, and 3 & 21,497 & 17,347 & 14,459 & 11,617 & 7520 \\
\hline
\end{tabular}

Note: Italic font in this table represents actual values in respective units.

In Table 4, the measured carbon footprint was calculated using the carbon calculator as discussed in Section 3.1. While the forecasted calculations were done on the premises; the university steering committee provides guidelines on targets which are based on university administration directives, and in accordance with the existing and past data. The targets for 2024, 2027, and 2030 were then extrapolated considering the mitigation measures. The reduction in emissions because of plantation as a mitigation activity was calculated based on the assumption that one tree sequesters approximately $22 \mathrm{~kg}$ of carbon dioxide per year, and the net carbon emissions were calculated by subtracting the emissions related to mitigation measures from total emissions. It can be seen in Table 4 that there is $38 \%$ reduction in emissions related to diesel for power generation, 20\% reduction in natural gas related emissions, and $17 \%$ reduction in emissions related to diesel for university buses from baseline year 2017 to 2021. This reduction is a result of switching to solar power, gas leakage/audit, and shifting to greener sources, and the introduction of electric vehicles for the first three components of Scope 1, respectively. For diesel power generation related emissions, it is estimated that by 2030,100\% emission reduction will be achieved. However, there is no change in emissions related to refrigerants and organic fertilizers as it has been decided by the steering committee that no further additions will be made. The increased reliance on water recycling is fulfilling the fertilizer requirement of green spaces. For Scope 2 , the purchased electricity related emissions have reduced to $23 \%$ from baseline year 2017 to 2021 because of the campus solarization project, and it is estimated that by 2030, 
$56 \%$ emission reduction will be achieved. For Scope 3, student and staff commute related emissions, there has been a reduction of $19 \%$ from baseline year to 2021 and it is estimated that by 2030 an emission reduction of $66 \%$ will be achieved. The emissions reduction has resulted from several initiatives taken by the university including awareness programs, student, faculty and staff involvement, promotion, healthy Friday, advocacy, carpooling, and cycling. Table 4 shows NED University will be able to achieve the carbon neutral status covering scopes 1 and 2 by 2030 .

\section{Limitations}

It is important to recognize the limitations of the carbon footprint calculations described in this paper. The organizational boundaries for carbon footprint calculation were the university main campus only, due to data unavailability from other campuses. Moreover, travel distances were assumed for staff and student commutation. There are many emission sources that could be evaluated for future carbon footprint calculations. For Scope 1, upstream emission sources such as raw materials extraction, processing, and transportation of fossil fuels could be used; and for Scope 3, emissions, food and beverages, furniture, laboratory supplies, maintenance supplies, machinery, infrastructure, and construction activities could be included. Furthermore, downstream impacts such as emissions linked with recycling, and the disposal of construction and demolition materials could also be included in the carbon footprint calculations. In the realm of socially inclusive and advocacy framework, it is necessary to conduct supplementary studies and surveys to measure the impacts of outreach activities.

\section{Conclusions}

Overall, this case study gives information on the estimation of carbon footprint of NED University, i.e., 21,500 MT e $\mathrm{CO}_{2}$ along with the identification of areas that contribute highest to its carbon footprint. This information is established as a baseline that is being used for adopting measures to further reduce the university's carbon footprint and make its operation more sustainable and carbon neutral by 2030. The successful implementation of various measures for embarking NED University on the mission of becoming carbon neutral and sustainable in a developing country are a result of robust leadership commitment along with the active engagement of faculty members, staff, students, and other relevant stakeholders. The present developing country university case study and other studies reported in literature demonstrate that transforming a university into a carbon neutral and sustainable campus is a stepwise and gradual process. However, there are no standard ways to become carbon neutral and sustainable. The transformation of a university into a carbon neutral and sustainable campus can become a source of motivation for the alteration of the local community and relevant stakeholders, thus trickling down its impact to wider segments of the society. Globally, universities can achieve carbon neutrality by first calculating their carbon footprint and then devising/implementing carbon mitigation strategies. Calculation of carbon footprint includes data collection, creation of inventory, marking of organizational, operational, and temporal boundaries, and subsequent feeding of data in the carbon calculator, while major carbon mitigation strategies include switching to renewables, usage of energy efficient appliances, electric vehicles, and massive tree plantation inside and outside the campus. The lessons learnt from this study could be transferrable to other universities located in different parts of the globe who intend to make their campus carbon neutral and sustainable. Hence, it can benefit other institutions and universities exploring their own transition to carbon-neutrality and sustainability.

Author Contributions: Conceptualization, A.M., M.K., S.A.Q.; methodology, A.M., M.K., S.A.Q.; software, A.M., M.K.; validation, H.R.K., S.H.L.; formal analysis, A.M., S.A.Q.; investigation, MK, H.R.K.; resources, A.M., S.A.Q., S.H.L.; data curation, H.R.K., S.H.L.; writing-original draft preparation, A.M.; writing—review and editing, A.M., M.K., S.A.Q.; visualization, M.K., H.R.K.; supervision, S.H.L.; project administration, A.M., S.H.L.; funding acquisition, S.A.Q., H.R.K. All authors have read and agreed to the published version of the manuscript. 
Funding: This research received partial funding from the Neurocomputation Lab, National Centre of Artificial Intelligence, NED University of Engineering and Technology, Karachi, Pakistan: PSDP.263/2017-18.

Acknowledgments: We would like to acknowledge support provided by the Green Society, Works and Services Department of NED University of Engineering and Technology, Industrial, and Civil Society contributors.

Conflicts of Interest: The authors declare no conflict of interest.

\section{References}

1. Hahn, R.; Kühnen, M. Determinants of sustainability reporting: A review of results, trends, theory, and opportunities in an expanding field of research. J. Clean. Prod. 2013, 59, 5-21. [CrossRef]

2. Barth, M.; Rieckmann, M. Academic staff development as a catalyst for curriculum change towards education for sustainable development: An output perspective. J. Clean. Prod. 2012, 26, 28-36. [CrossRef]

3. Wander, N.; Malone, R.E. Selling Off or Selling Out? Medical Schools and Ethical Leadership in Tobacco Stock Divestment. Acad. Med. 2004, 79, 1017-1026. [CrossRef]

4. Jain, S.; Aggarwal, P.; Sharma, N.; Sharma, P. Fostering sustainability through education, research and practice: A case study of TERI university. J. Clean. Prod. 2013, 61, 20-24. [CrossRef]

5. Bookhart, D. Strategies for carbon neutrality. Sustainability 2008, 1, 34-40. [CrossRef]

6. Jain, S.; Agarwal, A.; Jani, V.; Singhal, S.; Sharma, P.; Jalan, R. Assessment of carbon neutrality and sustainability in educational campuses (CaNSEC): A general framework. Ecol. Indic. 2017, 76, 131-143. [CrossRef]

7. Townsend, J.; Barrett, J. Exploring the applications of carbon footprinting towards sustainability at a UK university: Reporting and decision making. J. Clean. Prod. 2015, 107, 164-176. [CrossRef]

8. Alshuwaikhat, H.M.; Abubakar, I. An integrated approach to achieving campus sustainability: Assessment of the current campus environmental management practices. J. Clean. Prod. 2008, 16, 1777-1785. [CrossRef]

9. Velazquez, L.; Munguia, N.; Platt, A.; Taddei, J. Sustainable university: What can be the matter. J. Clean. Prod. 2006, 14, 810-819. [CrossRef]

10. Purcell, W.M.; Henriksen, H.; Spengler, J.D. Universities as the engine of transformational sustainability toward delivering the sustainable development goals: "Living labs" for sustainability. Int. J. Sustain. High. Educ. 2019, 20, 1343-1357. [CrossRef]

11. He, B.J.; Zhao, D.X.; Zhu, J.; Darko, A.; Gou, Z.H. Promoting and implementing urban sustainability in China: An integration of sustainable initiatives at different urban scales. Habitat Int. 2018, 82, 83-93. [CrossRef]

12. Gomez, N.; Cadarso, M.-A.; Monsalve, F. Carbon footprint of a university in a multiregional model: The case of the University of Castilla-La Mancha. J. Clean. Prod. 2016, 138, 119-130. [CrossRef]

13. United Nations. Higher Education Sustainability Initiative (HESI). Sustainable Development Goals-Knowledge Platform. 2020. Available online: https://sustainabledevelopment.un.org/sdinaction/hesi (accessed on 10 September 2021).

14. Opel, O.; Strodel, N.; Werner, K.F.; Geffken, J.; Tribel, A.; Ruck, W.K.L. Climate-neutral and sustainable campus Leuphana University of Lueneburg. Energy 2017, 126, 2628-2639. [CrossRef]

15. Carbon Neutral University-Sustainability. Available online: Csu.edu.au (accessed on 10 September 2021).

16. USF. University of San Francisco Achieves Carbon Neutrality More Than 30 Years Ahead of Goal. University of San Francisco. 2019. Available online: https://www.usfca.edu/newsroom/media-relations/news-releases/carbon-neutrality (accessed on 10 September 2021).

17. UC Davis. Climate Neutrality and Sustainability. Available online: https://energy.ucdavis.edu/research/research-initiatives/ climate-neutrality-and-sustainability/ (accessed on 30 August 2021).

18. The University of Bristol. Green Zero-Carbon Bristol. Available online: https://www.bristol.ac.uk/green/zero-carbon-bristol/ (accessed on 30 August 2021).

19. The University of Edinburgh. Zero by 2040. Available online: https://www.ed.ac.uk/sustainability/what-we-do/climatechange/initiatives/zero-by-2040 (accessed on 30 August 2021).

20. The University of Cape Town. UCT Carbon Footprint Report 2018. Available online: https://www.news.uct.ac.za/article/-202004-22-uct-carbon-footprint-report-2018 (accessed on 30 August 2021).

21. Harangozo, G.; Szigeti, C. Corporate carbon footprint analysis in practice-With a special focus on validity and reliability issues. J. Clean. Prod. 2017, 167, 1177-1183. [CrossRef]

22. Robinson, O.J.; Tewkesbury, A.; Kemp, S.; Williams, I.D. Towards a universal carbon footprint standard: A case study of carbon management at universities. J. Clean. Prod. 2018, 172, 4435-4455. [CrossRef]

23. Vazquez-Rowe, I.; Villanueva-Rey, P.; Mallo, J.; De la Cerda, J.; Moreira, T.; Feijoo, G. Carbon footprint of a multi-ingredient seafood product from a business to-business perspective. J. Clean. Prod. 2013, 44, 200-210. [CrossRef]

24. Clabeaux, R.; Carbajales-Dale, M.; Ladner, D.; Walker, T. Assessing the carbon footprint of a university campus using a life cycle assessment approach. J. Clean. Prod. 2020, 273, 122600. [CrossRef]

25. Udas, E.; Wölk, M.; Wilmking, M. The "carbon-neutral university"—A study from Germany. Int. J. Sustain. High. Educ. 2018, 19, 130-145. [CrossRef] 
26. Larsen, H.N.; Pettersen, J.; Solli, C.; Hertwich, E.G. Investigating the Carbon Footprint of a University-The case of NTNU. J. Clean. Prod. 2013, 48, 39-47. [CrossRef]

27. U.S. Environmental Protection Agency. Available online: https://www.epa.gov/energy/greenhouse-gases-equivalenciescalculator-calculations-and-references (accessed on 30 August 2021).

28. Raza, D.; Karim, R.B.; Nasir, A.; Khan, S.U.; Zubair, M.H. Satellite Based Surveillance of LULC with Deliberation on Urban Land Surface Temperature and Precipitation Pattern Changes of Karachi, Pakistan. J. Geogr. Nat. Disast. 2019, 9, 237. [CrossRef]

29. Miyawaki, A. Restoration of living environment based on vegetation ecology: Theory and practice. Ecol. Res. 2004, 19, 83-90. [CrossRef]

30. Clifford, D.; Petrescu, C. The keys to university-community engagement sustainability. Nonprofit Manag. Leadersh. 2012, 23, 77-91. [CrossRef]

31. Ozawa-Meida, L.; Brockway, P.; Letten, K.; Davies, J.; Fleming, P. Measuring carbon performance in a UK University through a consumption-based carbon footprint: De Montfort University case study. J. Clean. Prod. 2013, 56, 185-198. [CrossRef]

32. Letete, T.C.M.; Nothando, W.M.; Mondli, G.; Marquard, A. Carbon footprint of the university of cape town. J. Energy S. Afr. 2012, 22, 2-12. [CrossRef]

33. Klein-Banai, C.; Theis, T.L.; Brecheisen, T.A.; Banai, A. A greenhouse gas inventory as a measure of sustainability for an urban public research university. Environ. Pract. 2010, 12, 35-47. [CrossRef]

34. Jayathilake, H.M.; Thomas, E.W.; Nelson, L.; Dolman, P.; Bumrungsri, S.; Juthong, W.; Carrasco, L.R.; Edwards, D.P. Fruit trees and herbaceous plants increase functional and phylogenetic diversity of birds in smallholder rubber plantations. Biol. Conserv. 2021, 257, 109140. [CrossRef]

35. Lamb, D.; Erskine, P.D.; Parrotta, J.A. Restoration of degraded tropical forest landscapes. Science 2005, 310, 1628-1632. [CrossRef] [PubMed]

36. Fletcher, S.; Potts, J.S.; Heeps, C.; Pike, K. Public awareness of marine environmental issues in the UK. Mar. Policy 2009, 33, 370-375. [CrossRef]

37. Verhulst, E.; Lambrechts, W. Fostering the incorporation of sustainable development in higher education. Lessons learned from a change management perspective. J. Clean. Prod. 2015, 106, 189-204. [CrossRef]

38. Berchin, I.I.; Sima, M.; de Lima, M.A.; Biesel, S.; dos Santos, L.P.; Ferreira, R.V.; Ceci, F. The importance of international conferences on sustainable development as higher education institutions' strategies to promote sustainability: A case study in Brazil. J. Clean. Prod. 2018, 171, 756-772. [CrossRef] 